\title{
Shisha Consumption in Cotonou: Epidemiological Profile, Sanitary Consequences and Associated Factors
}

\author{
Aguemon Badirou ${ }^{1, *}$, Adounkpè Ferdinand ${ }^{2}$, Damien Barikissou Georgia ${ }^{3}$, Elegbede Fidélia $\mathbf{O}^{1}$, \\ Awédé Bonaventure ${ }^{4}$ \\ ${ }^{1}$ Public Health Unit, Faculty of Health Sciences, University of Abomey-Calavi, Republic of Benin \\ ${ }^{2}$ National Laboratory of Narcotics and Toxicology, Faculty of Health Sciences, Republic of Benin \\ ${ }^{3}$ Population and Health Department, Center for Training and Research in Population, University of Abomey-Calavi, Cotonou, \\ Republic of Benin \\ ${ }^{4}$ Human Physiology Unit, Faculty of Health Sciences, Republic of Benin
}

Received April 27, 2021; Revised July 14, 2021; Accepted August 22, 2021

\section{Cite This Paper in the following Citation Styles}

(a): [1] Aguemon Badirou, Adounkpè Ferdinand, Damien Barikissou Georgia, Elegbede Fidélia O, Awédé Bonaventure, "Shisha Consumption in Cotonou: Epidemiological Profile, Sanitary Consequences and Associated Factors," Universal Journal of Public Health, Vol. 9, No. 4, pp. 181 - 187, 2021. DOI: 10.13189/ujph.2021.090403.

(b): Aguemon Badirou, Adounkpè Ferdinand, Damien Barikissou Georgia, Elegbede Fidélia O, Awédé Bonaventure (2021). Shisha Consumption in Cotonou: Epidemiological Profile, Sanitary Consequences and Associated Factors. Universal Journal of Public Health, 9(4), 181 - 187. DOI: 10.13189/ujph.2021.090403.

Copyright $\odot 2021$ by authors, all rights reserved. Authors agree that this article remains permanently open access under the terms of the Creative Commons Attribution License 4.0 International License

\begin{abstract}
Introduction: Consumption of shisha is an increasingly popular form of smoking among young people around the world. This study aimed to determine the epidemiological profile of shisha consumers in Cotonou as well as socio-demographic associated factors with this practice. Methods: A cross-sectional survey was conducted in Cotonou from May to November 2020 among shisha consumers. The sample size was 427 . Non-probability convenience sampling with exhaustive selection of all consumers willing to participate in the study was performed. A questionnaire and an interview guide were administered to active and passive consumers respectively. A few samples of substances consumed by means of the shisha were collected and then analysed by Thin Layer Chromatography (TLC). Results: The mean age of the respondents was 22.38 years \pm 6.40 . The sex ratio (Male/Female) was 9.6. 55.3\% of those surveyed began to use shisha between the ages of 15 and 25 . They were mostly students $(59.5 \%)$ with a low monthly income. Up to $70 \%$ of respondents have already sought medical assistance for symptoms like cough $(36.84 \%)$, chest pain $(32.33 \%)$, sore throat $(27.83 \%)$, and abdominal burns $((3.0 \%)$. About $28 \%$ of respondents claim to become nervous after consumption. Substances such as tobacco $(35 \%)$, cannabis alone $(24 \%)$, cannabis/marijuana $(18 \%)$, cocaine $(16 \%)$, and alcohol $(7 \%)$ have been identified in
\end{abstract}

the products consumed. Conclusion: This investigation highlighted consumption of illicit drugs with shisha and the negative socio-health impacts linked to the consumption of shisha. The drug regulatory authorities should improve the control of shisha consumption in Benin especially among adolescents and youth.

Keywords Shisha, Chromatography, Illicit Drugs, Attributable Symptoms, Cotonou

\section{Introduction}

Tobacco use is a major public health problem. According to a World Health Organisation (WHO) estimate for 2019, approximately 1.1 billion people worldwide smoke [1]. Nearly 5 million people die each year worldwide due to diseases caused by tobacco use [2]. Tobacco is consumed mainly in smoked and smokeless forms. Shisha is one form of smoking tobacco. Shisha consumption reaches about 100 million people in secondary schools [3]. The use of shisha has increased significantly over the last decade, mainly due to its improved taste, lack of regulations and social acceptability as a safer option than cigarettes. There are many toxicity 
concerns associated with its use. In Africa, specifically in Benin, the prevalence of shisha was $13.86 \%$ among students in 2018 [4]. In order to better understand the factors associated with this consumption and to know the profile of shisha consumers and related consequences, we conducted a survey in the city of Cotonou at shisha consumption places. This study aimed to determine the epidemiological profile of shisha consumers in Cotonou as well as socio-demographic associated factors with this practice.

\section{Study Area and Methods}

\subsection{Study Area}

The survey was carried out in the 13 districts of the city of Cotonou (in restaurants and shisha bars and other specific places of consumption) and at the National Laboratory of Narcotics and Toxicology where psychoactive substances detection was done.

\subsection{Methods}

Type and period of study

A cross-sectional survey was conducted from July to October 2020.

Study population

The study population was consumers of chichia. The selection criteria were: i) have consumed shisha at least once in their life, ii) aged 10 years old or more and iii) be visited in restaurants, and shisha bars or others places of chichi consumption.

Sampling and sample size

It was a non-probability sampling. The exhaustive selection of all active and passive users willing to participate in the study was done. The sample size was based on the number of respondents.

Data collection: tools and technique

A semi-directive validated questionnaire was used to collect the information. Samples of the substances consumed as well as the consumption tools were collected for analysis in the laboratory. Before data collection a pre-test of the questionnaire and laboratory technics was done.

\section{Variables}

The dependent variable was the notion of recent or former shisha use and the independent variables were socio-demographic information, data on knowledge, attitudes, and practices about shisha, psycho-social and health characteristics.

\section{Data processing and analysis}

The data were analysed using Epi-info version 7.2.2.6. Socio-demographic characteristics and the prevalence of shisha consumption was described. For the bivariate analysis, the link between shisha consumption and socio-demographic variables was tested. For this purpose, Pearson's Khi2 test was used at the threshold of $\alpha$ equal to $5 \%$. The substances collected was analysed at National laboratory of drugs and toxicology. Thin Layer Chromatography (TLC) analysis of the sampled substances was performed for their identification.

\section{Results}

\section{Socio-demographic Characteristics}

A total of 427 people were enrolled in the study. The mean age was $22.38 \pm 6.40$ years. The extremes were 10 years and 45 years. In our series, the respondents were predominantly male with a sex ratio of 9.6. The most represented professional category was students $(59.5 \%)$. Most of the respondents were Beninese $(90.6 \%)$. They were mostly single $(63.9 \%)$. Most of the subjects had a low monthly income, less than or equal to 40,000 XOF (Table I). With regard to the age at which they started using drugs, $35.6 \%$ of the users started at less than 15 years, $55.27 \%$ between 15 and 25 years and only $9.13 \%$ after 25 years.

\section{Knowledge of the Chemical Composition of Shisha}

Among the respondents, $313(73.3 \%)$ have a good knowledge of the content of the substances that make up shisha. The association of stimulants and disruptors were the contents most mentioned $(50.8 \%)$, followed by disruptors only (28.4\%). Table 2 shows the respondents' perceptions on the nature of the different classes of psychoactive substances which composed shisha. 
Table 1. Socio-demographic characteristics of respondents, Cotonou, 2020

\begin{tabular}{|c|c|c|}
\hline Variables & Frequency (n) & Proportion (\%) \\
\hline \multicolumn{3}{|l|}{ Age (years) } \\
\hline $10-24$ & 298 & 69.8 \\
\hline $25-34$ & 109 & 25.5 \\
\hline$\geq 35$ & 20 & 4.7 \\
\hline \multicolumn{3}{|l|}{ Sex } \\
\hline Male & 387 & 90.6 \\
\hline Female & 40 & 9.4 \\
\hline \multicolumn{3}{|l|}{ Profession } \\
\hline Student & 254 & 59.5 \\
\hline Civil servant (public and private) & 69 & 16.2 \\
\hline Craftsman and Trader & 104 & 24.4 \\
\hline \multicolumn{3}{|l|}{ Nationality } \\
\hline Beninese & 387 & 90.6 \\
\hline Others & 40 & 9.4 \\
\hline \multicolumn{3}{|l|}{ Ethnicity } \\
\hline Yoruba/Nago & 103 & 24.1 \\
\hline Dendi/Bariba & 78 & 18.3 \\
\hline Fon and related parties & 246 & 57.6 \\
\hline \multicolumn{3}{|l|}{ Religion } \\
\hline Muslims & 160 & 37.5 \\
\hline Christian & 231 & 54.1 \\
\hline Others & 36 & 8.4 \\
\hline \multicolumn{3}{|l|}{ Marital status } \\
\hline Single & 273 & 63.9 \\
\hline Married or partnered & 145 & 34.0 \\
\hline Divorced or separated & 8 & 1.9 \\
\hline Widowed & 1 & 0.2 \\
\hline \multicolumn{3}{|l|}{ Type of household } \\
\hline Monogamous & 199 & 46.6 \\
\hline Polygamous & 228 & 53.4 \\
\hline \multicolumn{3}{|l|}{ Size of Household } \\
\hline$\leq 3$ & 207 & 48.5 \\
\hline$>3$ & 220 & 51.5 \\
\hline \multicolumn{3}{|l|}{ Monthly income (XOF) } \\
\hline$<20,000$ & 130 & 30.4 \\
\hline $20,000-40,000$ & 136 & 31.9 \\
\hline$>40,000$ & 161 & 37.7 \\
\hline
\end{tabular}

Table 2. Psychoactive substances present in shisha according to respondents, Cotonou, 2020.

\begin{tabular}{lcc}
\hline & \multicolumn{2}{c}{ Participants perception } \\
\cline { 2 - 3 } Psychoactive substances & Yes n (\%) & No n (\%) \\
\hline Stimulants & & $390(91.3)$ \\
Tea & $37(8.7)$ & $377(88.3)$ \\
Coffee & $50(11.7)$ & $411(96.3)$ \\
Amphetamine & $16(3.7)$ & $282(66.0)$ \\
Cocaine & $145(34)$ & $258(60.4)$ \\
Disruptors & & $260(60.9)$ \\
Tobacco & $169(39.6)$ & $375(87.8)$ \\
Alcohol & $167(39.1)$ & $412(96.5)$ \\
Cannabis & $52(12.2)$ & $416(97.4)$ \\
Depressants & & $393(92.0)$ \\
Heroin & $15(3.5)$ & $11(2.6)$ \\
Morphine & $34(8.0)$ & \\
Tramadol & & \\
\hline
\end{tabular}




\section{Shisha Composition and Sites of Consumption}

According to the respondents, the psychoactive substances consumed through shisha were most related to a mixed composition of shisha by added tobacco (35\%), cannabis alone $(24 \%)$, alcohol $(7 \%)$, cannabis/marijuana $(18 \%)$ and cocaine $(16 \%)$. The frequent places where shisha was consumed were shisha bars and nightclubs $(51.1 \%)$ as well as gaming centres or friends' homes $(42.4 \%)$, at home $(5.4 \%)$, and in the car $(1.2 \%)$.

\section{Harmful Effects Attributed to Shisha Consumption}

About $70 \%$ of the respondents presented symptoms that required a medical consultation after shisha consumption. They attributed these symptoms to shisha consumption. The symptoms were sore throat $(27.83 \%)$, chest pain (32.33\%), cough (36.84\%) and abdominal burning (3.0\%).

\section{Practices on Shisha Consumption and Places of Purchase}

The age range of initiation to shisha consumption among the respondents was between 15 and 25 years.
Moreover, $35.60 \%$ of the respondents were initiated to shisha consumption at a very young age (under 15 ). The majority of participants reported that they regularly use shisha $(58.3 \%)$, the most of them with friends $(83.1 \%)$, and preferably in the evening $(84.3 \%)$. Shisha is sold either in shisha bars or in oriental shops. The majority of participants were aware of the health risks associated with shisha consumption $(75.2 \%)$, (Table 3 ).

\section{Negative Perception and Sanitary Consequences Linked to Shisha Consumption}

Among the participants to the study, 53\% perceived that Shisha was more dangerous than smoking and $48.7 \%$ declared that they can stop using shisha if necessary.

Of the respondents, $60 \%$ think that the shisha consumption can lead to lung, mouth and throat cancers and $24 \%$ the lung infection. $70 \%$ of the participants declared that they presented symptoms which need medical visits after shisha consumption. The main symptoms they cited were cough (37\%); thoracic pain (32\%); throat pains (28\%), and abdominal burns (3\%).

Table 3. Practices of shisha consumption, Cotonou, 2020

\begin{tabular}{|c|c|c|}
\hline Variables & Frequency (n) & Proportion (\%) \\
\hline \multicolumn{3}{|l|}{ Mode of operation } \\
\hline Alone & 41 & 9,6 \\
\hline With family & 31 & 7,3 \\
\hline Friends & 355 & 83,1 \\
\hline \multicolumn{3}{|l|}{ Rate of consumption } \\
\hline Regularly (Weekly) & 249 & 58,3 \\
\hline Occasionally & 131 & 30,7 \\
\hline Rarely & 47 & 11,0 \\
\hline \multicolumn{3}{|l|}{ Time of consumption } \\
\hline Morning & 11 & 2,6 \\
\hline Afternoon & 56 & 13,1 \\
\hline Evening & 360 & 84,3 \\
\hline \multicolumn{3}{|l|}{ Place of sale } \\
\hline Shisha bar & 232 & 54,3 \\
\hline Oriental shops & 195 & 45,7 \\
\hline \multicolumn{3}{|l|}{ Favourable appreciation } \\
\hline Smoke (taste, smell, sweetness) & 288 & 67,4 \\
\hline Aesthetics of the machine & 17 & 4,0 \\
\hline Pleasure of sharing in a group & 32 & 7,5 \\
\hline Follow-up a group & 22 & 5,2 \\
\hline Smoking and aesthetics of the machine & 33 & 7,7 \\
\hline Smoking and group sharing & 35 & 8,2 \\
\hline \multicolumn{3}{|l|}{ Unfavourable appreciation } \\
\hline Any comments & 13 & 3,0 \\
\hline Cold smoke & 33 & 7,7 \\
\hline Bulky size of the machine & 60 & 14,1 \\
\hline Negative impact on health & 321 & 75,2 \\
\hline \multicolumn{3}{|l|}{ Reason of consumption } \\
\hline Pleasure/Distraction/Boredom & 347 & 81,3 \\
\hline Family and work problems & 49 & 11,7 \\
\hline Lack of appetite/Staying awake & 31 & 7,2 \\
\hline
\end{tabular}




\section{Factors Associated with Shisha Consumption}

Factors statistically associated with shisha consumption were age, gender, occupation, period of shisha consumption, pleasure and displeasure parameters (Table $4 \mathrm{a}$ and $4 \mathrm{~b}$ ).

Table 4a. Factors associated to shisha consumption, Cotonou, 2020.

\begin{tabular}{|c|c|c|c|}
\hline \multirow[b]{2}{*}{ Variables } & \multicolumn{2}{|c|}{ Shisha consumption } & \multirow[b]{2}{*}{$\mathbf{p}$} \\
\hline & $\begin{array}{c}\text { Recent } \\
\text { n (\%) }\end{array}$ & $\begin{array}{c}\text { Previous } \\
\text { n (\%) } \\
\end{array}$ & \\
\hline \multicolumn{4}{|l|}{ Sex } \\
\hline Female & $25(13.8)$ & $15(6.1)$ & \multirow[t]{2}{*}{0.007} \\
\hline Male & $156(86.2)$ & $231(93.9)$ & \\
\hline \multicolumn{4}{|l|}{ Age (years) } \\
\hline $10-24$ & $143(79.0)$ & $155(63.0)$ & \multirow{3}{*}{0.002} \\
\hline $25-34$ & $32(17.7)$ & $77(31.3)$ & \\
\hline$\geq 35$ & $6(3.3)$ & $14(5.7)$ & \\
\hline \multicolumn{4}{|l|}{ Profession } \\
\hline Student & $129(71.3)$ & $125(50.8)$ & \multirow{3}{*}{$<0.0001$} \\
\hline Civil servant (public and private) & $21(11.6)$ & $48(19.5)$ & \\
\hline Craftsman and Trader & $31(17.1)$ & $73(29.7)$ & \\
\hline \multicolumn{4}{|l|}{ Type of household } \\
\hline Monogamous & $89(49.2)$ & $110(44.7)$ & \multirow[t]{2}{*}{0.362} \\
\hline Polygamous & $92(50.8)$ & $136(55.3)$ & \\
\hline \multicolumn{4}{|l|}{ Size of household } \\
\hline$\leq 3$ & $90(49.7)$ & $117(47.6)$ & \multirow[t]{2}{*}{0.659} \\
\hline$>3$ & $91(50.3)$ & $129(52.4)$ & \\
\hline \multicolumn{4}{|l|}{ Monthly income (XOF) } \\
\hline$<20,000$ & $60(33.1)$ & $70(28.5)$ & \multirow{3}{*}{0.746} \\
\hline $20,000-40,000$ & $57(31.5)$ & $79(32.1)$ & \\
\hline$>40,000$ & $64(35.4)$ & $97(39.4)$ & \\
\hline \multicolumn{4}{|l|}{ Time of consumption } \\
\hline Morning & 11 & 2,6 & \multirow{3}{*}{0.006} \\
\hline Afternoon & 56 & 13,1 & \\
\hline Evening & 360 & 84,3 & \\
\hline
\end{tabular}

Table 4b. Factors associated to shisha consumption, Cotonou, 2020.

\begin{tabular}{|c|c|c|c|}
\hline \multirow[b]{2}{*}{ Variables } & \multicolumn{3}{|c|}{ Shisha consumption } \\
\hline & $\begin{array}{c}\text { Recent } \\
\text { n (\%) }\end{array}$ & $\begin{array}{c}\text { Previous } \\
\text { n (\%) }\end{array}$ & $\mathbf{p}$ \\
\hline \multicolumn{4}{|l|}{ Favourable appreciation } \\
\hline Smoke (taste, smell, sweetness) & & & \multirow{7}{*}{0.012} \\
\hline Aesthetics of the machine & $138(76.2)$ & $150(61.0)$ & \\
\hline Pleasure of sharing in a group & $4(2.2)$ & $13(5.3)$ & \\
\hline Follow-up a group & $14(7.7)$ & $18(7.3)$ & \\
\hline Smoking and aesthetics of the machine & $5(2.8)$ & $17(6.9)$ & \\
\hline Smoking and group sharing & $11(6.1)$ & $22(8.9)$ & \\
\hline Reason of consumption & $9(5.0)$ & & \\
\hline & $152(84.0)$ & $195(79.3)$ & \multirow{3}{*}{0.667} \\
\hline Pleasure/Distraction/Boredom & $18(9.9)$ & $31(12.6)$ & \\
\hline Family/work problems & $11(6.1)$ & $20(8.2)$ & \\
\hline \multicolumn{4}{|l|}{ Unfavourable appreciation } \\
\hline Any comments & $0(0)$ & $13(5.3)$ & \multirow{4}{*}{0.001} \\
\hline Cold smoke & $8(4.4)$ & $25(10.2)$ & \\
\hline Bulky size of the machine & $26(14.4)$ & $34(13.8)$ & \\
\hline Negative impact on health & $147(81.2)$ & $174(70.7)$ & \\
\hline
\end{tabular}




\section{Chromatographic Analysis of Collected Products}

The different product samples collected from consumers and analysed by chromatography allowed the identification of the following psychoactive substances: cannabis, heroin, cocaine, tramadol, shisha flavouring, and paracetamol.

\section{Discussion}

\section{Limitations}

The health consequences of consumption were assessed on the basis of subjective symptoms reported by the consumers after shisha consumption, which required medical advice. These reports alone are not sufficient to effectively explore the health effects of shisha consumption-clinical investigations could be carried out in future studies.

\section{Socio-demographic Characteristics of the Users and the Psychoactive Substances Consumed by Means of Shisha}

The average age of the shisha users surveyed was 22.38 \pm 6.40 years. Hessami et al., reported in Iran in 2016 a higher average age of $28.01 \pm 6.40$ [5]. This difference between our study and that of Hessami et al., could be explained by the fact that our study population consisted of subjects aged 10 years and older, whereas that of Hessami et al., consisted of respondents aged 15 years and older. Therefore, it is important to reinforce actions by creating and improving laws related to the consumption of shisha mostly towards the adolescent and youth $[6,7]$. Shisha users were predominantly male. Our results corroborate those of several authors. Salih et al., reported a prevalence of $42.5 \%$ of male and $27 \%$ of female students at the University of Jazon in Saudi Arabia [8]. The work of Primack et al., reported that women were more attracted to the milder flavoured types of tobacco marketed as more social and exotic than shisha flavour [9]. More than half of our respondents $(62.3 \%)$ had a low monthly income of less than 40,000 XOF. This result could be explained by the fact that more than half of the consumers were students. The main source of income of the latter would come from their parents.

The age range of initiation to shisha consumption among the respondents was between 15 and 25 years. Moreover, $35.60 \%$ of the respondents were initiated to shisha consumption at a very young age (under 15). Several other authors found that the age of initiation was within this age range $[10,11]$. Shisha is therefore initiated at a young age. In order to protect future generations, it is important to consider actions targeted specifically at youth with regard to shisha consumption.
In the course of the study, $35.1 \%$ of the respondents mentioned shisha tobacco with different flavours as the most commonly used substance. These respondents also mentioned other substances such as the mixture of shisha tobacco and cannabis, marijuana, cocaine, and alcohol. Sutfin et al., in 2014 reported that shisha users reported smoking flavoured tobacco, marijuana and hashish through their shisha [12]. Similarly, Abraham et al., in Nigeria in 2019 reported that tobacco in shisha was in some cases replaced or mixed with other drugs such as marijuana [13]. Toxicological analysis of the different substances collected during the study allowed the identification and confirmation of reported substances such as illicit drugs (cocaine, heroin and cannabis), paracetamol and tramadol. The conclusion is that the users of illicit drugs have found, through the shisha, a more discreet way of consuming them without attracting any attention. During the study, the symptoms (sore throat, chest pain, cough, and abdominal burning) attributed to the shisha consumption were common, and less serious than those already reported by the literature. Aslam et al., reported that exposure to shisha smoking is significantly associated with low infant weight, heart rate variations, hyperglycaemia and hypertriglyceridemia and increased risk of carcinoma [14].

\section{Sanitary Consequences of Shisha}

People who smoke hookah may be at risk for some of the same diseases as cigarette smokers. These include oral, lung, oesophagus and stomach cancer, the reduced of lung function, the decreased of fertility, heart diseases, and others as already described [15-17].

\section{Conclusions}

Shisha smoking is quite widespread and is mostly observed among adolescents and youth in Benin. Shisha tobacco was sometimes mixed with, or substituted for, illicit drugs such as cannabis, cocaine and heroin. The Knowledge of shisha harmful effects and chemical composition is not a guarantee of reluctance. Action must be taken to eradicate this phenomenon among adolescent and youth.

\section{Acknowledgement}

We acknowledge all the participants of the study.

\section{Conflict of Interest}

The authors declare that they have no conflict of interests. 


\section{REFERENCES}

[1] World Health Organization (WHO). Tobacco. Key facts. Geneva: WHO, 2020. Available from: https://www.who.int/fr/news-room/fact-sheets/detail/tobac co, (accessed Apr. 22, 2021).

[2] Fouda S., Kelany M., Moustafa N., Abushouk A.I., Hassane A., Sleem A., et al., "Tobacco smoking in Egypt: A scoping literature review of its epidemiology and control measures", Eastern Mediterranean health journal, vol. 24 no. 2, pp. 198-215, 2018. DOI:10.26719/2018.24.2.198.

[3] AlQahtany F.S., Algahtani F.H., Alshebly M.M., Madkhaly F.M., Ghandour M.K., Almalki J.H., et al., "Association between cigarette \& shisha smoking and the severity of polycythemia: A cross sectional study", Saudi Journal of Biological Sciences, vol. 27, no. 1, pp. 460-464, 2019. DOI:10.1016/j.sjbs.2019.11.009.

[4] Wachinou A.P., Djidonou A., Agodokpessi G., Fandohan O., Salanon E., Fiogbe A., et al., "Shisha smoking among students in Cotonou in 2018: prevalence and associated factors", Revue des Maladies Respiratoires Actualités, vol. 12, no. 1, pp.138-139, 2020. DOI:10.1016/j.rmra.2019.11. 300 .

[5] Hessami Z., Masjedi M.R., Mortaz E., Heydari G., Kazempour-Dizaji M., Sharifi H., et al., "Evaluation of dual tobacco smoking (water pipe and cigarettes) and associated factors in adults in Tehran", Tanaffos, vol. 15, no. 3, pp. 180-186, 2016.https://www.ncbi.nlm.nih.gov/pmc/articles /PMC5304963/

[6] Syed N., Rani K., Memon M.Q., "Shisha-smoking; popularity and familiarity among university students of Jamshoro and Hyderabad, Sindh, Pakistan", The Professional Medical Journal, vol. 22, no. 2, pp. 200-203, 2015. Available from: https://www.researchgate.net/public ation/275654027 SHISHA-SMOKING (accessed Apr. 27, 2021).

[7] Badran M., Laher I., "Waterpipe (shisha, hookah) smoking, oxidative stress and hidden disease potential", Redox Biology, vol. 34, no. 101455, 2020. DOI: 10.1016/j.redox.2020.101455.

[8] Salih S., Shaban S., Athwani Z., Alyahyawi F., Alharbi S., Ageeli F., et al., "Prevalence, Predictors, and Characteristics of Waterpipe Smoking Among Jazan
University Students in Saudi Arabia: A Cross-Sectional Study", Annals of Global Health, vol. 86, no. 1, pp. 87, 2020. DOI:http://doi.org/10.5334/aogh.2912.

[9] Primack B.A., Carroll M.V., Shensa A., Davis W., Levine M.D., "Sex Differences in Hookah-Related Images Posted on Tumblr: A Content Analysis", Journal of Health Communication, vol. 21 , no. 3 , pp. $366-375,2016$. DOI: 10.1080/10810730.2015.1095814.

[10] Sabahy A.R., Divsalar K., Bahreinifar S., Marzban M., Nakhaee N., "Waterpipe tobacco use among Iranian university students: Correlates and perceived reasons for use", The International Journal of Tuberculosis and Lung Disease, vol.15, no. 6, pp. 844-847, 2011. DOI: 10.5588/ijtld.10.0744.

[11] Jawad M., Abass J., Hariri A., Rajasooriar K.G., Salmasi H., Millett C., et al., "Waterpipe smoking: Prevalence and attitudes among medical students in London", International Journal of Tuberculosis and Lung Disease, vol. 17, no. 1, pp. 137-140, 2013. DOI: 10.5588/ijtld.12.0175.

[12] Huang L.L., Sutfin E.L., Kowitt S., Patel T., Ranney L., Goldstein A.O., "Trends and Correlates of Hookah Use Among High School Students in North Carolina", North Carolina Medical Journal, vol. 78, no. 3, pp.149-155, 2017. DOI: $10.18043 / \mathrm{ncm} .78 .3 .149$.

[13] Abraham E.A., Egbe C.O., Ayo-Yusuf O.A., "News media coverage of shisha in Nigeria from 2014 to 2018", Tobacco Induced Disease, vol. 17, pp. 33. 2019. DOI: $10.18332 / \mathrm{tid} / 106139$.

[14] Aslam H.M., Saleem S., German S., Qureshi W.A., "Harmful effects of shisha: literature review", International Archives of Medicine, vol. 7, pp. 16, 2014. DOI: 10.1186/1755-7682-7-16.

[15] American Lung Association. Facts About Hookahexternal icon Washington: American Lung Association, 2007 https://www.lung.org/quit-smoking/smoking-facts/health-e ffects/facts-about-hookah (accessed Apr. 22; 2021).

[16] Akl E.A., Gaddam S., Gunukula S.K., Honeine R., Jaoude P.A., Irani J, "The Effects of Waterpipe Tobacco Smoking on Health Outcomes: A Systematic Review.external icon", International Journal of Epidemiology vol. 39, pp. 834-857, 2010. DOI: $10.1093 / \mathrm{ije} /$ dyq002.

[17] Cobb C.O., Ward K.D., Maziak W., Shihadeh A.L., Eissenberg T., "Waterpipe Tobacco Smoking: An Emerging Health Crisis in the United States.external icon". American Journal of Health Behavior vol. 34, no. 3, pp. 275-285, 2010. PMID: 20001185 